\title{
A bone-seeking clone exhibits different biological properties from the ACHN parental human renal cell carcinoma in vivo and in vitro
}

\author{
JIANG WANG, ANMIN CHEN, CAIHONG YANG, HENG ZENG, JUN QI and FENG-JIN GUO \\ Department of Orthopedics, Tongji Hospital, Tongji Medical College, \\ Huazhong University of Science and Technology, Wuhan 430030, P.R. China
}

Received November 2, 2011; Accepted November 21, 2011

DOI: $10.3892 /$ or.2011.1572

\begin{abstract}
Metastatic bone disease caused by renal cell carcinoma (RCC) occurs frequently. Very little is currently known about the mechanism of preferential metastasis of RCC to bone. We hypothesize that RCCs that develop bone metastases have the capacity to facilitate their colonization in bone. To examine this hypothesis, we established bone-seeking (ACHN-BO) clones of the human RCC cell line ACHN by repeated four passages in nude mice and in vitro of metastatic cells obtained from bone. These clones were examined for distinguishing biological characteristics and compared with the ACHN parental cells (ACHN-P) in vivo and in vitro. Our results showed that the ACHN-BO cell line could be successfully obtained by in vivo selection through the lateral tail vein. This approach results in the development of multiple osteolytic lesions in the distal femora and proximal tibiae within four weeks after inoculation, with a success rate of $85-100 \%$ and no additional comorbidity. ACHN-P cells developed metastases in lung, bone, brain, ovary and adrenal glands. Conversely, ACHN-BO cells exclusively metastasized to bones with larger osteolytic lesions. Compared with the ACHN-P cell line, the proliferation ability in ACHNBO6 was increased by 9.68 and $6.42 \%$, respectively $(\mathrm{P}<0.05)$, while the apoptotic ratio decreased significantly $(\mathrm{P}<0.05)$ and cells were blocked in the $\mathrm{S}$ phase with suppressed migration and invasion capacities. The $\mathrm{ACHN}-\mathrm{BO}_{6}$ cell line produced greater amounts of the pro-angiogenic factors VEGF and TGF- $\beta$ than ACHN-P. Our data suggest that these phenotypic changes allow RCC cells to promote osteoclastic bone resorption, survive and proliferate in bone, which consequently leads to the establishment of bone metastases. This model provides a reliable
\end{abstract}

Correspondence to: Dr Feng-jin Guo, Department of Orthopedics, Tongji Hospital, Tongji Medical College, Huazhong University of Science and Technology, Wuhan 430030, P.R. China

E-mail: guofengjintjgk@163.com

Key words: renal cell carcinoma, bone metastasis, in vivo selection, animal model development reproduction of the clinical situation and, therefore, is suitable for designing and evaluating more effective treatments for RCC bone metastasis.

\section{Introduction}

Renal cell carcinoma (RCC) is a common malignancy (1) and $>35 \%$ of patients dying with RCC have skeletal metastases (2). These skeletal metastases cause devastating complications including intractable bone pain, pathological fractures, and hypercalcemia (2-4). Thus, bone metastasis in RCC is one of the major causes of increased morbidity and eventual mortality and a therapeutic target in RCC patients. Clinically their care is challenging for the orthopaedic surgeon because of the highly lytic, vascular nature of the tumors (5). In order to affect any improvement in survival from this inherently chemo- and radio-resistant disease (6-8), a better understanding of the molecular mechanisms involved in RCC growth in bone is required.

Generally, it has been recognized that cytokine secretion by RCC cells into the local microenvironment modulates host immune response, tumor growth and metastasis (9). RCC are highly vascular tumors, which overproduce angiogenic factors such as vascular endothelial growth factor (VEGF) $(9,10)$. Most cancer cells produce transforming growth factor- $\beta$ (TGF- $\beta$ ) and a high level of TGF- $\beta$ secretion is thought to increase the malignant potential of the tumor. Increased plasma levels of TGF- $\beta$ were described as a tumor marker and prognostic factor in RCC (11). The pro-inflammatory cytokines interleukin-6 (IL-6) and interleukin-8 (IL-8) were also predominantly produced by RCC (12-15). IL-6 in particular is an autocrine growth factor for RCC and seems to be tumor protecting against cytotoxic tumor-infiltrating lymphocytes $(11,16-17)$. The importance of the TGF- $\alpha$ /EGF-R signaling pathway in RCC bone metastasis has been elucidated by Weber et al (9).

We reasoned these phenotypic changes might be responsible for the mechanism of preferential metastasis of RCC to bone. To examine this hypothesis, we established bone-seeking (ACHNBO) clones of the human RCC cell line ACHN by repeated sequential passages in nude mice and in vitro of metastatic cells obtained from bone. These clones were examined for distinguishing biological characteristics and compared with the 
ACHN parental cells (ACHN-P) in vivo and in vitro. We found that the bone-seeking clone of ACHN cells has several different biological properties from those of the ACHN parental cells. Our data suggest that these phenotypic changes may allow RCC cells to develop and accelerate bone metastases.

\section{Material and methods}

Cell cultures. ACHN cells, a human renal cancer line, were from China Center of Type Culture Collection (CCTCC), Wuhan (China). ACHN cells were maintained in DMEM/F12 (1:1) medium supplemented with $10 \%$ heat-inactivated fetal bovine serum. All cell lines were incubated at $37^{\circ} \mathrm{C}$ in a humidified atmosphere of $5 \% \mathrm{CO}_{2}$ in air.

Animals. For selection in vivo, 6- to 8-week-old female nude mice (BALB/c-nu) were obtained from the Experimental Animal Center of Huazhong University of Science and Technology (Wuhan, China). All animals in our study were housed under pathogen-free conditions and maintained according to the guidelines of the Committee on Animals of Huazhong University of Science and Technology.

In vivo selection of $A C H N-B O$. Female nude mice (BALB/c-nu, 5-week-old) were anesthetized with 5\% Rompun/10\% Ketavet in $0.9 \% \mathrm{NaCl} / 10 \mathrm{~g}$ body weight before injection. We injected $0.1 \mathrm{ml}$ of tumor cells ( $5 \times 10^{5}$ cells) into the lateral tail vein of anesthetized BALB/c-nu mice using an insulin syringe as described by Otsuka et al (18). Mice with osteolytic lesions in the hind limbs caused by ACHN-P line detected by radiography (osteolytic lesions in hind limbs were monitored every 7 days starting from day 28) were sacrificed and the affected hind limb was separated from the body. Skin and muscles were removed and the hind limb was mashed with a piston through a sieve in a petridish containing $10 \mathrm{ml}$ of $0.9 \% \mathrm{NaCl}$ medium. Tumor cell suspension was collected from the petridish into a T-75 flask. The next day, cells were washed twice with PBS to wash off mouse bone marrow cells that did not attach to the plate. After 3 weeks, a population of human cancer cells was obtained. These subpopulations $\left(\mathrm{ACHN}-\mathrm{BO}_{1}\right)$ were again inoculated into the lateral tail vein of anesthetized female BALB/c-nu. Following four passages of in vivo selection a highly bone metastatic cell line, $\mathrm{ACHN}-\mathrm{BO}_{4}$, was obtained. The mice were sacrificed when they lost $>10 \%$ of their body weight.

Radiographic analysis of osteolytic lesions. Osteolytic lesions in hind limbs were monitored every 7 days starting from day 28 using a Digital Faxitron small animal X-ray cabinet (Faxitron X-Ray, Wheeling, IL, USA) at $35 \mathrm{kV}$ tube voltage, $0.3 \mathrm{~mA}$ current and 4 sec exposure time. Lesion area in hind limbs was quantified using image analysis software (Analysis Software Imaging System GmbH, Germany).

Bone histology. For histological examination, hind limbs were removed from mice after being sacrificed, fixed in $4 \%$ buffered formalin (Merck \& Co. Inc., USA), decalcified in $10 \%$ EDTA (Sigma-Aldrich, Munich, Germany), dehydrated and embedded in paraffin. Tissue sections of $4 \mu \mathrm{m}$ thick were cut and stained with hematoxylin and eosin (H\&E) using standard protocols.
Cell growth assay. To assess possible impacts of in vivo selection on ACHN cells malignant biological behaviors. The cells were trypsinized, counted, plated and assayed for cell proliferation, migration and invasion in triplicate experiments by our research group (19). For proliferation assays, cells in the log-growth phase were harvested, suspended at a density of $\sim 1 \times 10^{4}$ cells $/ \mu 1$ and seeded into triplicate wells of 96-well plates at $100 \mu \mathrm{l} /$ well. After $24 \mathrm{~h}$ of culture, $50 \mu \mathrm{l}$ of $1 \mathrm{X}$ MTT was added to each well. The plates were then incubated at $37^{\circ} \mathrm{C}$ for $4 \mathrm{~h}$. After removal of the supernatants, the precipitates were solubilized in DMSO (150 $\mu \mathrm{l} /$ well) and shaken for $20 \mathrm{~min}$. The absorbances of the wells were measured at a wavelength of $450 \mathrm{~nm}$.

Sterile polycarbonate membrane filters (Corning Inc., New York, NY) with $8-\mu \mathrm{m}$ pores were coated with $6 \mu \mathrm{g} / \mathrm{ml}$ Matrigel gelatin (BD Co., Franklin Lakes, NJ). The filters were hydrated with $200 \mu \mathrm{l}$ of serum-free medium at $37^{\circ} \mathrm{C}$ for $60 \mathrm{~min}$ before use. Cells $\left(5 \times 10^{4}\right)$ were seeded into the top chambers of 6-well plates, and the lower chambers were filled with $500 \mu \mathrm{l}$ of DMEM/F12 (1:1) medium containing 10\% FBS for $24 \mathrm{~h}$. The filters were fixed with $95 \%$ alcohol and stained with hematoxylin for $15 \mathrm{~min}$. The cells on the upper surface were gently removed with a cotton swab and the cells on the lower surface of the filters were quantified under a microscope at a magnification of $\mathrm{x} 400$.

For invasion assays, Matrigel-coated sterile $8-\mu \mathrm{m}$ polyethylene filters were rehydrated as described above. The lower chambers of 24-well plates were filled with $1 \mathrm{ml}$ of DMEM/F12 (1:1) medium containing $10 \mu \mathrm{g}$ of fibronectin as a chemoattractant and $0.5 \mathrm{ml}$ of serum-free DMEM/F12 (1:1) containing $5 \times 10^{4} \mathrm{ACHN}-\mathrm{P}(\mathrm{BO})$ cells was added to the upper chambers for $48 \mathrm{~h}$. Subsequently, the cells were stained with hematoxylin and the numbers of cells that had invaded the filters were recorded.

Cell apoptosis assay. Cells were harvested using trypsin/EDTA in phosphate-buffered saline (PBS; Biochrom), counted, and collected by centrifugation in PBS. Phosphatidylserine (PS) exposure on the outer leaflet of the plasma membrane was detected using the fluorescent dye Annexin V-FITC Apoptosis Detection kit according to the manufacturer's instructions. In brief, cells were rinsed with ice-cold PBS and then resuspended in $200 \mu \mathrm{l}$ of binding buffer. Annexin V stock solution $(10 \mu \mathrm{l})$ was added to the cells and incubated for $30 \mathrm{~min}$ at $4^{\circ} \mathrm{C}$. The cells were then further incubated with $5 \mu \mathrm{l}$ propidium iodide (PI) and were immediately analyzed on a FACSC-LSR (Becton Dickinson) equipped with CellQuest (Becton Dickinson) software; $\sim 5 \times 10^{5}$ cells were collected in each of the samples and $5 \times 10^{4}$ cells were analyzed.

ELISAs to measure production of growth factors and cytokines. The production and secretion of TGF- $\alpha$, VEGF, bFGF, and IL-6 (Uscn Life Science Inc., Wuhan, China) by the ACHN-P cell line and the highly metastatic subpopulation $\left(\mathrm{ACHN}-\mathrm{BO}_{4}\right)$ were determined in cell culture supernatants after $48 \mathrm{~h}$ of culture using a quantitative sandwich enzyme immunoassay technique (ELISA) according to manufacturer's instructions. Triplicates were measured.

Data analysis. Data are expressed as the means \pm standard deviations. Statistical analyses were performed using Student's 
A

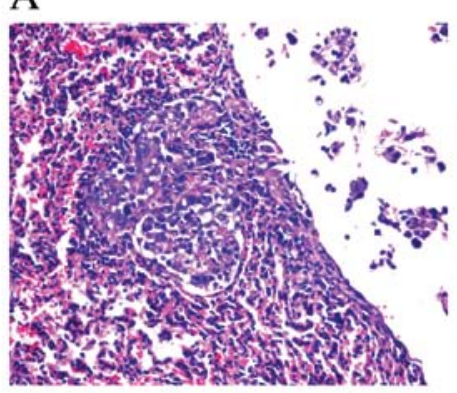

$\mathrm{B}$

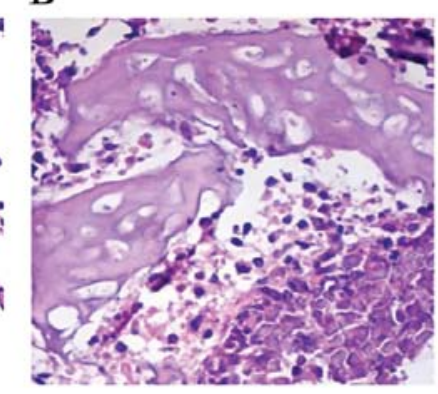

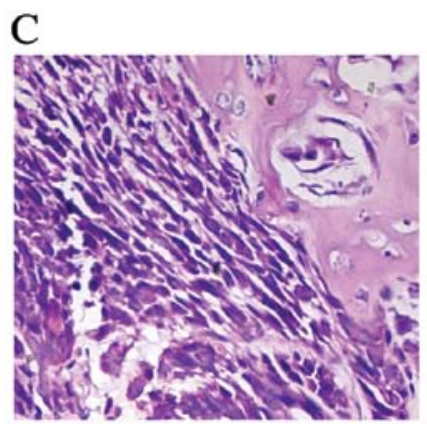

Figure 1. Histological examination of lung (A) and humerus bone metastasis sites (B and C). The sections were thin-cut and stained with hematoxylin and eosin (original magnification, $\mathrm{x} 200$ ).

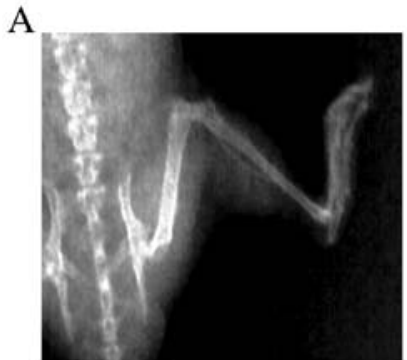

a

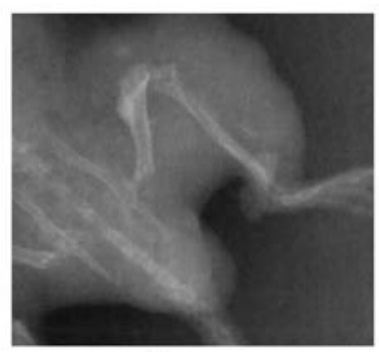

c

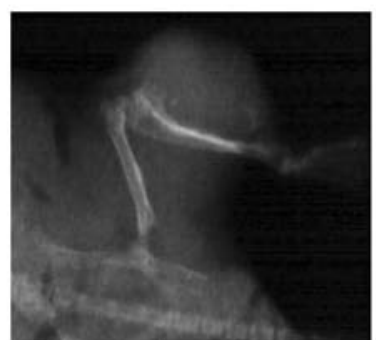

b

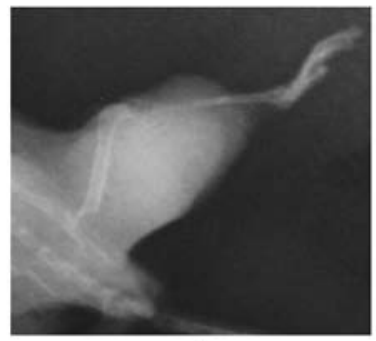

d
B

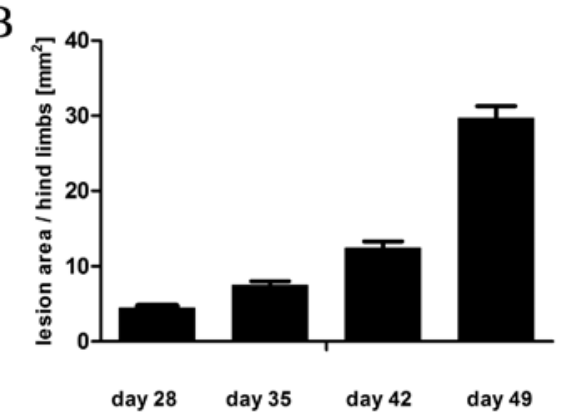

Figure 2. The constinual increase of the osteolytic lesion area in $\mathrm{ACHN}-\mathrm{BO}_{6}$ bone metastasis model. (A) Representative radiographs showing one hind limb monitored weekly from day 28 until day 49. (B) Mean osteolytic lesion area of hind limbs as measured by radiography ( $\mathrm{n}=8$ for each time point).

$\mathrm{t}$-test. Differences were considered to be statistically significant when the P-value was $<0.05$.

\section{Results}

The establishment of ACHN-BO cell line. In the first cycle of inoculation, 25\% (3/12) of the transplanted mice with ACHN-P cells inoculated through the lateral tail vein had tumor clones in bone (the time point was 6 weeks), the remaining 75\% (9/12) of the transplanted mice were observed for 4 months and no bone metastasis and no tumor-related death were found. The lung metastasis rates were 100\% (11/11) (Fig. 1A). The bone metastasis tumor clones were dissected and used for primary cell culture; these bone metastasis tumor cells were confirmed as ACHN-BO1 cells with histological analysis (Fig. 1B) and chromosomal karyotype analysis (data not shown). In the second cycle of inoculation, $\sim 42 \%(5 / 12)$ of the transplanted mice had bone metastasis. Starting with the third cycle, higher percentage of the bone metastasis in the transplanted mice was observed. All of the transplanted mice had bone metastasis after the fifth inoculation (12/12). Most of the bone metastasis sites were spine and the four limbs. In addition, the tumor cells can also translocate to adrenal glands, sub-mandibular glands, lung and lymph nodes, etc. We named the sixth cycled bone metastasis cells as ACHN-BO ${ }_{6}$ with histological analysis confirmation (Fig. 1C).

Symptoms of the RCC bone metastasis model resemble clinical setting. After $\mathrm{ACHN}-\mathrm{BO}_{5}$ cell inoculation, all animals developed aggressive osteolytic bone metastasis as monitored by radiography with the endpoint at a mean of 6 weeks. First lesions were observed by radiography 4 weeks after tumor cell inoculation. Fig. 2A shows the time course of the development of osteolytic lesions monitored weekly from day 28 until day 56 by radiography. The determination of mean lesion size from the X-ray images indicated a steady increase of the osteolytic lesion area (Fig. 2B). The observed extensive bone destruction was similar to those noted in clinical settings and mainly occurred in tibia, femur, fibula, forelimbs, spine and sometimes in pelvis.

The proliferation, migration and invasion of ACHN cells in vitro. As shown in Fig. 3A, compared with ACHN-P cell lines; the ACHN-BO exhibited increased cell proliferation by $2.17 \%\left(\mathrm{ACHN}-\mathrm{BO}_{2}\right)$ and $0.81 \%\left(\mathrm{ACHN}-\mathrm{BO}_{5}\right)$ for the first $48 \mathrm{~h}$, respectively $(\mathrm{P}<0.05)$. After $96 \mathrm{~h}$, the proliferation was significantly increased by 8.97 and $4.72 \%$, respectively $(\mathrm{P}<0.05)$. No difference in tumor cell proliferation and in vivo tumor growth between the cell lines could be observed (Fig. 3A). We further evaluated whether the selected cell lines altered the motility of ACHN cells across Transwell polycarbonate membranes. As shown in Fig. 3B and C, compared with ACHN-Ps, the cell migration and invasiveness of ACHN-BO were reduced by $46.71 \%\left(\mathrm{ACHN}-\mathrm{BO}_{2}\right)$ and $54.24 \%\left(\mathrm{ACHN}-\mathrm{BO}_{5}\right)$, respectively 


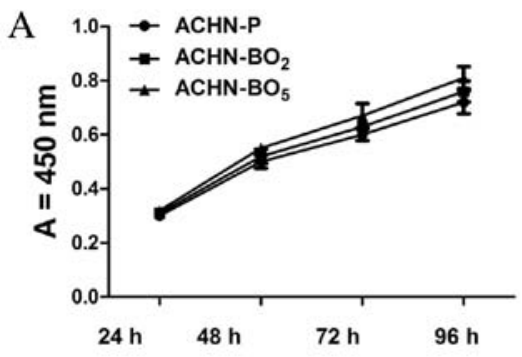

Growth Curves of Three Cell Groups

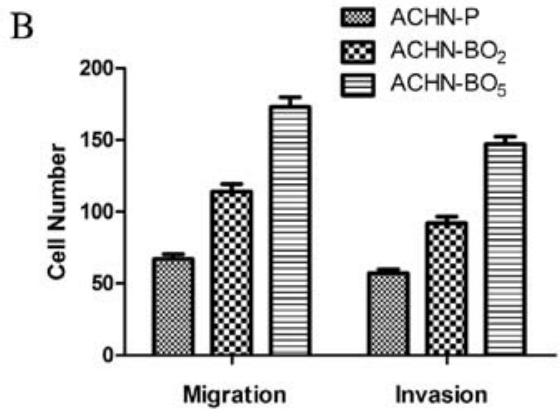

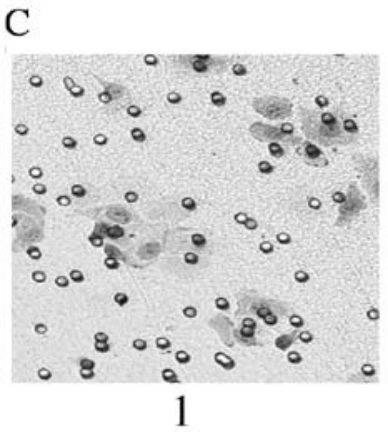
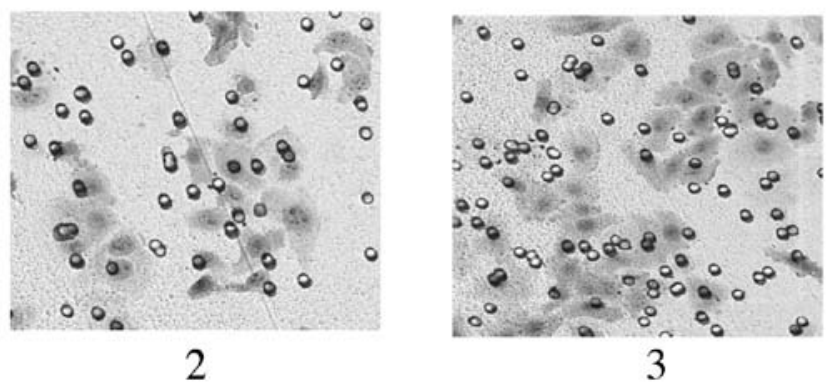

Figure 3. The in vivo selection increased proliferation, migration and invasion of ACHN cells. (A) Growth curves of three cell groups evaluated by MTT assays. (B) Comparisons of the cell migration and invasion activities among three cell groups. Compared with ACHN-Ps, the cell migration and invasiveness of $\mathrm{ACHN}-\mathrm{BO}$ were reduced by $46.71 \%\left(\mathrm{ACHN}-\mathrm{BO}_{2}\right)$ and $54.24 \%\left(\mathrm{ACHN}-\mathrm{BO}_{5}\right)$, respectively $(\mathrm{P}<0.05)$. (C) The typical invasion photographs of three groups. 1, ACHN-P; $2, \mathrm{ACHN}_{-} \mathrm{BO}_{2} ; 3, \mathrm{ACHN}_{-} \mathrm{BO}_{5}$.

A

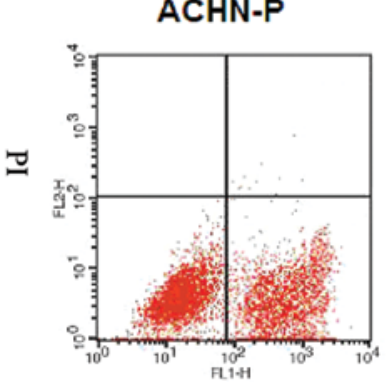

$\mathrm{ACHN}-\mathrm{BO} 2$

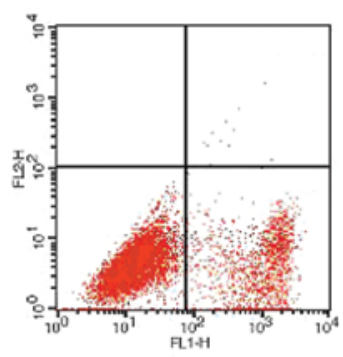

Annexin V
ACHN-BO5

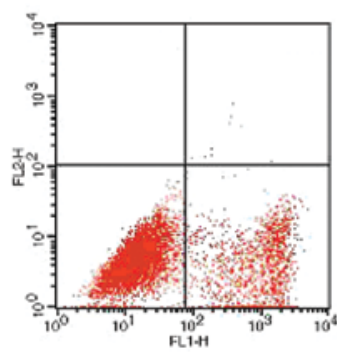

$(\%)$
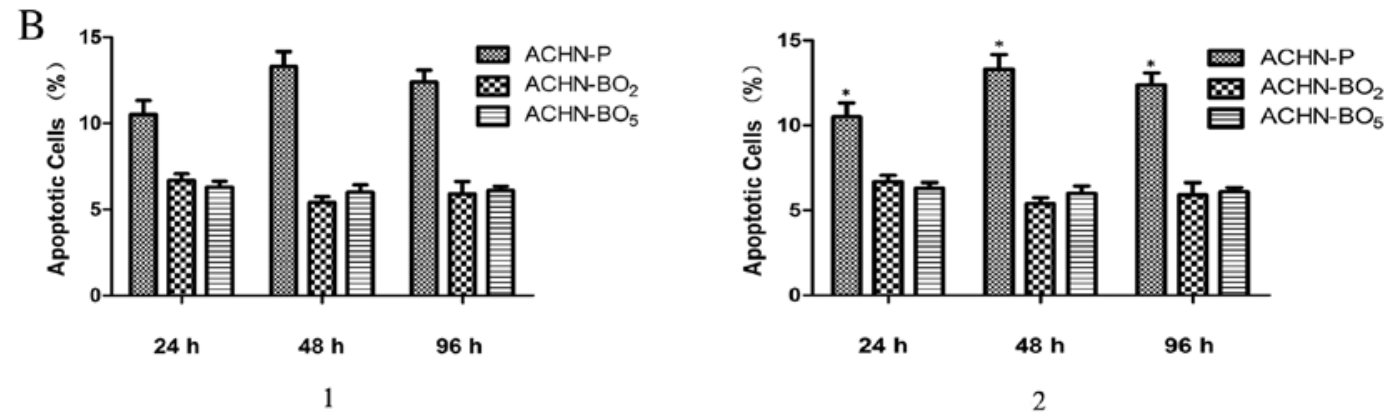

Figure 4. LSS triggers anti-apoptosis in MSCs. MSCs were incubated for 12 and $24 \mathrm{~h}$. (A) Apoptosis was then quantified by FACS analysis after staining with Annexin V and propidine iodide (PI). The Annexin $\mathrm{V}^{+} / \mathrm{PI}^{-}$(B1) cells are early in the apoptotic process. Viable cells are Annexin $\mathrm{V}^{-} / \mathrm{PI}^{-}(\mathrm{B} 2)$. Each data point represents mean \pm standard deviation of three independent experiments. ${ }^{*} \mathrm{P}<0.05$ vs. static control.

$(\mathrm{P}<0.05)$. Taken together, these data suggest that the ACHN-BO cell line significantly inreased the proliferation, migration and invasion of ACHN cells in vitro.
Effects of in vivo selection on ACHN apoptosis. Cell apoptosis was measured using fluorescent dye Annexin V-FITC, which binds to phosphatidylserine residues that are redistributed from 
A

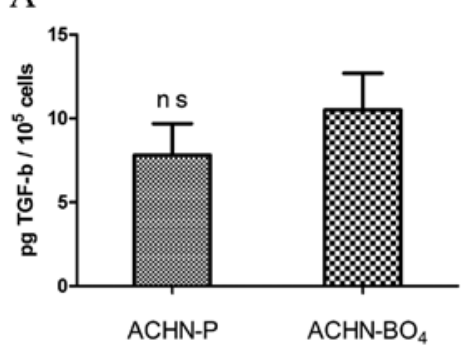

$\mathrm{C}$

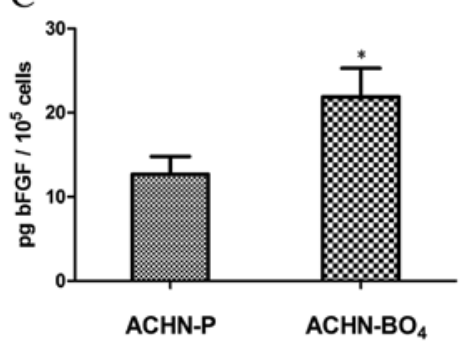

B

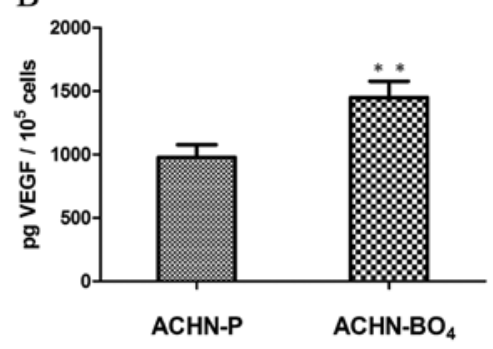

$\mathrm{D}$

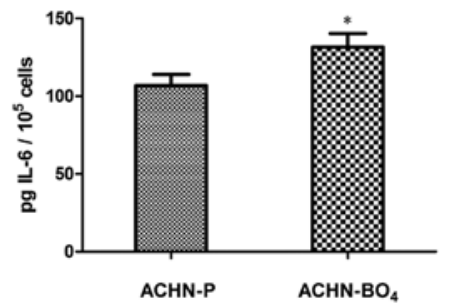

Figure 5. In vitro characterization of the in vivo selected cell line. Parental and high metastatic cell lines were characterized by quantitative ELISA of (A) TGF- $\beta$, (B) VEGF, (C) bFGF and (D) IL-6 in vitro (these growth factors and cytokines have been suggested to be important in RCC bone metastasis). Subpopulation $\mathrm{ACHN}-\mathrm{BO}_{4}$ showed higher secretion of the pro-angiogenic factors VEGF and bFGF, of the osteolytic factor IL-6 compared to the parental cell line. Mean \pm SD values shown $\left({ }^{*} \mathrm{P}<0.05 ;{ }^{* *} \mathrm{P}<0.01 ; \mathrm{ns}\right.$, not significant).

the inner to the outer leaflet of the cell membrane as an early event in apoptosis. After loss of membrane integrity, PI can enter the cell and intercalate into DNA. Annexin $\mathrm{V}^{+} / \mathrm{PI}^{+}$cells were considered necrotic cells, whereas Annexin $\mathrm{V}^{+} / \mathrm{PI}^{-}$cells were counted as apoptotic cells. Fig. 4 shows the percentages of Annexin V-stained and PI-stained cells of ACHN cell lines. The percentage of Annexin $\mathrm{V}^{+} / \mathrm{PI}^{-}$cells was reduced to $10.4 \%$ compared with the static control value of $13.1 \%$ after $24 \mathrm{~h}$ and was reduced to $9.7 \%$ compared with the static control value of $12.3 \%$ after $48 \mathrm{~h}$. With a longer incubation $(96 \mathrm{~h})$, the population of Annexin $\mathrm{V}^{+} / \mathrm{PI}^{+}$cells was much smaller than that of the static control (3.5 vs. $12.7 \%$ ). These data suggest that the ACHN- BO cell lines had a reduced cell apoptosis compared to ACHN-P cell lines.

The expression of various growth factors and cytokines. The subpopulation with high metastatic potential, $\mathrm{ACHN}-\mathrm{BO}_{4}$, showed higher or equivalent expression of all analyzed growth factors and cytokines compared with the parental cell line (Fig. 5). The secretion of TGF- $\alpha$ was on the same level in the $\mathrm{ACHN}-\mathrm{BO}_{4}$ cell line $\left(10.5 \pm 2.2 \mathrm{pg}\right.$ TGF- $\alpha / 10^{5}$ cells $)$ as in the parental cell line $\left(7.8 \pm 1.9\right.$ pg TGF- $\alpha / 10^{5}$ cells, $\left.\mathrm{P}=0.148\right)$ (Fig. 5A). Pro-angiogenic factors, such as VEGF and bFGF, were significantly induced in the highly metastatic $\mathrm{ACHN}-\mathrm{BO}_{4}$ in vivo selected cell line compared to the parental cell line. VEGF levels were significantly higher in the $\mathrm{ACHN}-\mathrm{BO}_{4}$ cell line, with a mean of $1450 \pm 129 \mathrm{pg} \mathrm{VEGF} / 10^{5}$ cells compared with $978 \pm 101 \mathrm{pg} \mathrm{VEGF} / 10^{5}$ cells in the parental cell line group $(\mathrm{P}=0.009)$. bFGF secretion was $\sim 2$-fold higher in the highly metastatic cell line with $21.9 \pm 3.4 \mathrm{pg} b F G F / 10^{5}$ cells compared with $12.7 \pm 2.1 \mathrm{pg} b F G F / 10^{5}$ cells in the parental cell line ( $\mathrm{P}=0.026)$ (Fig. 5B and C). Similarly, the level of IL-6 was also significantly elevated in the highly metastatic cell line (131.7 $\pm 8.6 \mathrm{pg}$ IL-6/10 5 cells) compared to parental cell line (106.8 \pm 7.2 pg IL-6/105 cells; $\mathrm{P}=0.019)$ (Fig. 5D).

\section{Discussion}

In the present study, we validated a model of human RCC bone metastasis as clinically relevant. It rapidly forms growing osteolytic bone metastases after intravenous injection to nude mice and displays distinguishing biological characteristics. We showed that the ACHN-BO cell line has unique properties through the in vivo body imaging and subpopulation cell line culture in vitro.

Animal models of metastasis have supported drug development and have been useful for identification of metastasis suppressor and promoter genes as novel targets for therapies $(20,21)$. After tail vein injection of ACHN cells, the development of osteolytic lesions were observed after 4 weeks. This nude mouse model is therefore very robust and properly reflects the bone metastatic process observed in the clinic. Tumor cell injection into the left heart ventricle is the standard technique used to induce bone metastasis (22). Intratibial injection of tumor cells is also a challenging procedures to induce bone metastasis (23). Our model requires a more straightforward route of injection. These cells are inoculated intratibially and develop osteolytic lesions similar to those in patients.

TGF- $\beta$ is among the most abundant growth factor stored in bone (24-26). TGF- $\beta$ is released continually into the bone marrow cavity in active form as a consequence of bone resorption during physiological bone remodeling (27). Therefore, it is likely that the growth of breast cancer cells metastasized in bone are under the influence of bone derived TGF- $\beta$. TGF- $\beta$ generally is known as a tumor suppressor and inhibits the growth of most cancer cells in culture (28-30). In this study, we have shown that the anchorage-independent growth of the ACHN parental cells and the bone-seeking clone is inhibited significantly by TGF- $\beta$. In contrast, TGF- $\beta$ failed to suppress the anchorage-independent growth of the bone-seeking clone, suggesting that the bone-seeking clone is resistant to the 
growth inhibitory effect of TGF- $\beta$. Our data suggest that this resistance is unlikely because of changes in the expression and activation of TGF- $\beta$ signaling pathways such as type I and type II receptors, Smad2, Smad3, Smad6, and Sma7. It is possible that other mechanisms that have been shown recently to cause the resistance of cancer cells to the growth inhibitory effect of TGF- $\beta$ [41-44] play a role (31-33).

As hypervascularity is associated with RCC bone metastasis, we analyzed the pro-angiogenic factors VEGF and bFGF which are reported to be crucial for angiogenesis, proliferation, survival and spread of cancer cells (34). We were able to demonstrate that VEGF and bFGF are induced in the highly metastatic $\mathrm{ACHN}$ in vivo selected subpopulation compared to the parental ACHN cell line. As reported, the induction of pro-angiogenic factors in the majority of RCC cases is due to the inactivation of the von Hippel-Lindau (VHL) tumor suppressor gene, which is also known to be missing in ACHN cells. The loss of VHL leads to stabilization of hypoxia-inducible factor-1 $\alpha$ (HIF-1 $\alpha$ ) which in turn results in the expression of many proangiogenic factors such as VEGF (35). VEGF is the most important angiogenic cytokine and its overexpression contributes to the typical hypervascular histology of clear cell RCC (36).

Elevated levels of IL-6, an autocrine tumor growth factor produced by RCC cells, correlated with a poor outcome in patients with metastatic RCC (37). Serum levels of IL-6 were detectable in the majority of patients with metastatic renal cell carcinoma and showed a significant correlation to progressionfree survival and overall survival (38).

Taken together, the characterization of the ACHN bone metastasis model and the consequent in vivo selection approach are the basis for the identification of factors implicated in RCC bone metastasis and provide a possibility to evaluate and improve promising drug candidates. Characteristics of the bone-seeking clones in vivo and in vitro compared with the ACHN parental cells are distinguish. Our results suggest that these capacities are at least necessary for RCC to develop and accelerate bone metastases. However, it should be noted that these capacities are not specifically attributable to bone metastasis of breast cancer and that additional yet unknown properties are likely involved. In this context, the bone-seeking clone we described herein should provide a useful model for identification of novel genes or molecules that are responsible for bone metastasis in RCC.

\section{References}

1. Figlin RA: Renal cell carcinoma: management of advanced disease. J Urol 161: 381-387, 1999.

2. Zekri J, Ahmed N, Coleman RE and Hancock BW: The skeletal metastatic complications of renal cell carcinoma. Int J Oncol 19: 379-382, 2001.

3. Jemal A, Tiwari RC, Murray T, et al: Cancer statistics, 2004. CA Cancer J Clin 54: 8-29, 2004

4. Galasko CS: Bone metastases studied in experimental animals. Clin Orthop Relat Res 1981: 269-285, 1981

5. Durr HR, Maier M, Pfahler M, Baur A and Refior HJ: Surgical treatment of osseous metastases in patients with renal cell carcinoma. Clin Orthop Relat Res 283-290, 1999.

6. Iwai A, Fujii Y, Kawakami S, et al: Down-regulation of vascular endothelial growth factor in renal cell carcinoma cells by glucocorticoids. Mol Cell Endocrinol 226: 11-17, 2004.

7. Takahashi A, Sasaki H, Kim SJ, et al: Markedly increased amounts of messenger RNAs for vascular endothelial growth factor and placenta growth factor in renal cell carcinoma associated with angiogenesis. Cancer Res 54: 4233-4237, 1994.
8. Motzer RJ and Russo P: Systemic therapy for renal cell carcinoma. J Urol 163: 408-417, 2000.

9. Weber K, Doucet M and Kominsky S: Renal cell carcinoma bone metastasis - elucidating the molecular targets. Cancer Metastasis Rev 26: 691-704, 2007.

10. Takahashi N, MacDonald BR, Hon J, et al: Recombinant human transforming growth factor-alpha stimulates the formation of osteoclast-like cells in long-term human marrow cultures. J Clin Invest 78: 894-898, 1986.

11. Kominsky SL, Doucet M, Brady K and Weber KL: TGF-beta promotes the establishment of renal cell carcinoma bone metastasis. J Bone Miner Res 22: 37-44, 2007.

12. Mydlo JH, Michaeli J, Cordon-Cardo C, Goldenberg AS, Heston WD and Fair WR: Expression of transforming growth factor alpha and epidermal growth factor receptor messenger RNA in neoplastic and nonneoplastic human kidney tissue. Cancer Res 49: 3407-3411, 1989.

13. Aebersold DM, Froehlich SC, Jonczy M, et al: Expression of transforming growth factor-alpha, epidermal growth factor receptor and platelet-derived growth factors $\mathrm{A}$ and $\mathrm{B}$ in oropharyngeal cancers treated by curative radiation therapy. Radiother Oncol 63: 275-283, 2002.

14. Pan J, Mestas J, Burdick MD, et al: Stromal derived factor-1 (SDF-1/CXCL12) and CXCR4 in renal cell carcinoma metastasis. Mol Cancer 5: 56, 2006.

15. Rosol TJ, Tannehill-Gregg SH, LeRoy BE, Mandl S and Contag CH: Animal models of bone metastasis. Cancer 97: 748-757, 2003.

16. Arguello F, Baggs RB and Frantz CN: A murine model of experimental metastasis to bone and bone marrow. Cancer Res 48: 6876-6881, 1988 .

17. Yoneda T, Sasaki A, Dunstan C, et al: Inhibition of osteolytic bone metastasis of breast cancer by combined treatment with the bisphosphonate ibandronate and tissue inhibitor of the matrix metalloproteinase-2. J Clin Invest 99: 2509-2517, 1997.

18. Otsuka S, Hanibuchi M, Ikuta K, et al: A bone metastasis model with osteolytic and osteoblastic properties of human lung cancer ACC-LC-319/bone2 in natural killer cell-depleted severe combined immunodeficient mice. Oncol Res 17: 581-591, 2009.

19. Liu H, Chen A, Guo F and Yuan L: A short-hairpin RNA targeting osteopontin downregulates MMP-2 and MMP-9 expressions in prostate cancer PC-3 cells. Cancer Lett 295: 27-37, 2010.

20. Kelland LR: Of mice and men: values and liabilities of the athymic nude mouse model in anticancer drug development. Eur J Cancer 40: 827-836, 2004.

21. Bibby MC: Orthotopic models of cancer for preclinical drug evaluation: advantages and disadvantages. Eur J Cancer 40: 852-857, 2004.

22. Hawk ET, Umar A, Lubet RA, Kopelovich L and Viner JL: Can animal models help us select specific compounds for cancer prevention trials? Recent Results Cancer Res 166: 71-87, 2005.

23. Shaw TJ, Senterman MK, Dawson K, Crane CA and Vanderhyden BC: Characterization of intraperitoneal, orthotopic, and metastatic xenograft models of human ovarian cancer. Mol Ther 10: 1032-1042, 2004.

24. Hauschka PV, Mavrakos AE, Iafrati MD, Doleman SE and Klagsbrun M: Growth factors in bone matrix. Isolation of multiple types by affinity chromatography on heparin-Sepharose. J Biol Chem 261: 12665-12674, 1986.

25. Pfeilschifter J and Mundy GR: Modulation of type beta transforming growth factor activity in bone cultures by osteotropic hormones. Proc Natl Acad Sci USA 84: 2024-2028, 1987.

26. Kretzschmar M, Doody J, Timokhina I and Massague J: A mechanism of repression of TGFbeta/Smad signaling by oncogenic Ras. Genes Dev 13: 804-816, 1999.

27. Luo K, Stroschein SL, Wang W, et al: The Ski oncoprotein interacts with the Smad proteins to repress TGFbeta signaling. Genes Dev 13: 2196-2206, 1999.

28. Onichtchouk D, Chen YG, Dosch R, et al: Silencing of TGF-beta signalling by the pseudoreceptor BAMBI. Nature 401: 480-485, 1999.

29. Stroschein SL, Wang W, Zhou S, Zhou Q and Luo K: Negative feedback regulation of TGF-beta signaling by the SnoN oncoprotein. Science 286: 771-774, 1999.

30. Dvorak HF: Vascular permeability factor/vascular endothelial growth factor: a critical cytokine in tumor angiogenesis and a potential target for diagnosis and therapy. J Clin Oncol 20: 4368-4380, 2002.

31. Rini BI and Small EJ: Biology and clinical development of vascular endothelial growth factor-targeted therapy in renal cell carcinoma. J Clin Oncol 23: 1028-1043, 2005. 
32. Gorospe M, Egan JM, Zbar B, et al: Protective function of von Hippel-Lindau protein against impaired protein processing in renal carcinoma cells. Mol Cell Biol 19: 1289-1300, 1999.

33. Semenza G: Signal transduction to hypoxia-inducible factor 1. Biochem Pharmacol 64: 993-998, 2002.

34. Iguchi H, Yokota M, Fukutomi M, et al: A possible role of VEGF in osteolytic bone metastasis of hepatocellular carcinoma. J Exp Clin Cancer Res 21: 309-313, 2002.

35. Yang Q, McHugh KP, Patntirapong S, Gu X, Wunderlich L and Hauschka PV: VEGF enhancement of osteoclast survival and bone resorption involves VEGF receptor-2 signaling and beta3integrin. Matrix Biol 27: 589-599, 2008.
36. Hurley MM, Lee SK, Raisz LG, Bernecker P and Lorenzo J: Basic fibroblast growth factor induces osteoclast formation in murine bone marrow cultures. Bone 22: 309-316, 1998.

37. Blay JY, Negrier S, Combaret V, et al: Serum level of interleukin 6 as a prognosis factor in metastatic renal cell carcinoma. Cancer Res 52: 3317-3322, 1992.

38. Negrier S, Perol D, Menetrier-Caux C, et al: Interleukin-6, interleukin-10, and vascular endothelial growth factor in metastatic renal cell carcinoma: prognostic value of interleukin-6 - from the Groupe Francais d'Immunotherapie. J Clin Oncol 22: 2371-2378, 2004 